\title{
Knowledge Sharing Practices, Intellectual Capital and Organizational Performance
}

\author{
Mrs.Mujid Attar \\ University of Technology \\ Sydney \\ MujidMarwanO.Attar@student. \\ $\underline{\text { uts.edu.au }}$
}

\author{
Dr.Kyeong Kang \\ University of Technology \\ Sydney \\ $\underline{\text { Kyeong.Kang@uts.edu.au }}$
}

\author{
Dr.Osama Sohaib \\ University of Technology \\ Sydney \\ Osama.Sohaib@uts.edu.au
}

\begin{abstract}
Although knowledge sharing and intellectual capital are significant factors for long-term success of an organization, existing literature rarely examines the relationship between knowledge sharing practices intellectual capital (IC) as constitutive elements of a knowledge environment leading to enhanced operational performance. The main aim of this paper is to explore whether knowledge sharing practices (types, approaches, and process) and intellectual capital affect organizational operational performance. Findings suggest that knowledge sharing types and knowledge sharing process influence intellectual capital of an organization. Moreover, intellectual capital influences organizational operational performance. However, knowledge sharing approaches, i.e. codification and personalization strategies have no effect on intellectual capital.
\end{abstract}

\section{Introduction}

An organization with efficient knowledge sharing systems is likely to improve the productivity of employees [1]. Developing efficient knowledge sharing systems may require the organization to think strategically through its knowledge sharing approaches, process and knowledge types. Strategic knowledge management approaches are an underlying force for superior innovation and market performance [2]. Knowledge management in the organization encompasses multiple aspects, but this paper concentrates on knowledge sharing practices of an organization as a core factor for improved operational performance.

Knowledge sharing involves "activities of transferring or disseminating knowledge from one person, group or organization to another" [3]. Knowledge sharing remains a challenge among organizations because finding the right set of data, information and knowledge for a task is always difficult and often leads to under-utilization [4, 5]. In this paper, we argue that improving knowledge sharing requires a comprehensive view of an organization's knowledge sharing environment. A knowledge-sharing environment will comprise of the knowledge types utilized in the organization, the knowledge sharing processes and the knowledge sharing approaches that enable the organization to preserve and reuse knowledge productively.

Additionally, organizations need to shape their knowledge-sharing environment both in terms of the knowledge flows through knowledge sharing and knowledge stocks through intellectual capital (IC) development [6]. As knowledge sharing enables knowledge transfer for improved individual work performance [7, 8], IC creates organizational value from such knowledge transfer [6,9]. In fact, an organization creates value when it supports the interaction between human capital and other forms of IC through sufficient knowledge management strategies [10]. However, IC development through knowledge sharing practices remains insufficiently discussed.

Further still, extant literature on knowledge sharing rarely identifies the differences between knowledge sharing practices of an organization and their role on IC development. Consequently, the mediating role of IC in the relationship between knowledge sharing practices and organizational operational performance remains under explored. This paper argues that the organization's knowledge sharing environment constitutes four factors significant for enhancing operational performance, i.e. the type of knowledge emphasized in the organization, the knowledge sharing processes in the organization, the knowledge sharing approaches (codification or personalization) and the IC of the organization.

\section{Literature Review}

\subsection{Knowledge Sharing Practices}


Knowledge is a firm's most valued resources. Sharing knowledge is important for developing skills and increasing value for enhanced competitive advantage. It is imperative for organizations to recognize three aspects that can define their knowledge-sharing practices - (1) the knowledge sharing processes, (2) the type of knowledge shared in the organization and (3) its knowledge sharing approaches.

Knowledge sharing is the process by which the knowledge is distributed across the organization. Organisations must recognize the two processes of knowledge sharing, i.e. knowledge donation and knowledge collection. Knowledge donation is the processes of 'communicating to others one's IC' [11]. During knowledge donation, the donors dedicate their valuable time to record and post their codified knowledge, skills and experiences on the share media for others to receive and reconstruct the knowledge to foster action. Therefore, communication processes and information flows are fundamentally a major driver for knowledge donation in organizations. Knowledge collection, on the other hand, involves consulting others to access their IC [11]. Given the duality of the knowledge sharing processes [12], collecting, seeking or receiving knowledge are core process that must occur for knowledge donation to be relevant.

In addition, there are two types of knowledge shared in an organization's knowledge sharing environment - tacit or explicit depending on the need of the problem in question. Tacit knowledge is articulable, partially articulable or in-articulable [13]. Tacit knowledge need not be converted to explicit but expressed in new ways that allow it to be displayed and manifested through social interactions [14]. Consequently, the technology through which individuals share tacit knowledge, the approach or strategy to tacit knowledge sharing and the degree of tacitness are important considerations for organizations [15-17]. Explicit knowledge, on the other hand, is structured and formalised. Although knowledge creation begins with tacit knowledge sharing through socialization, organization will codify tacit knowledge to create explicit knowledge through externalization, combination and internalization [18]. Therefore, comparing and understanding tacit and explicit knowledge processes remains crucial in the organization [19].

Further still, knowledge sharing may occur through both formal and informal process. For example, knowledge can be shared between employee's informal process such as meetings, seminars and workshops, or through company knowledge databases and internal documents. It is thus important to evaluate an organization's knowledge sharing practices by acknowledging personalization approaches as informal knowledge sharing processes and codification as a formal knowledge sharing process. Adopting a codification approach implies that the core focus of the organization is to collect and organize knowledge [20]. This approach is recognized for reducing costs of knowledge acquisition and improving reliability of knowledge storage and recall [21]. Social constructivists, on the other hand, suggest that knowledge is a social artefact produced through shared understandings emerging due personalization (socialization and interaction) [22]. Personalization develops a rich and flexible medium for communication, which is related to the use of people's contrivance for knowledge sharing [23]. It allows individuals, as custodians of knowledge, to share and discuss experiences to create new knowledge [24].

\subsection{Intellectual Capital (IC)}

Intellectual capital "is the term given to the combined intangible assets which enable the company to function" [25]. The common elements of IC are human capital, structural capital, and relational capital [26-32]. These elements go hand in hand because "a simultaneous coordination of human capital, structural capital and relational capital is required to drive business performance" [33].

Human capital is the sum of employees' competence, knowledge, skills, innovativeness, attitude, commitment, wisdom, and experience [3335]. It represent the individual knowledge stock of an organization [35]. It is the intangible assets that employees cannot take away when getting off work or leaving organizations. IC is best described as the valuable strategic assets of organizational capabilities, organizational culture, routines, procedures, information systems, hardware, software, databases, company images, patents, copyrights, trademarks, and so on [35-37]. IC also exists in relationships between an organization and its external stakeholders [34]. Moreover, IC creates organizational value by connecting internal intellectual resources with external stakeholders [38].

Structural capital, on the other hand, relates to the relationships held between individuals within the organization and the product or service systems of the firm $[34,36]$. Structural capital consists of mechanisms and organizational procedures, which support the employees in completing their tasks. For human capital developed by employees successfully used, operative procedures and communication systems are required which aimed at supporting the activities of each employee [34]. An organization with strong structural capital will have a supportive culture 
that allows individuals to try things, to fail, to learn, and to try again supporting the contribution that the single employees can be given to the company [34]. Structural capital allows human capital to develop and grow within the organization. Structural capital occurs as knowledge contained in the procedures and in the organizational routines used by the employee, consciously or not, during the carrying out of a task [25].

Relational capital is "the strength and loyalty of customer relations" [36]. It is built on ex-firm intangibles such as knowledge embedded in customers, suppliers and the industry at large [34]. From a relational capital view, a relationship includes multiple facets that are reflected by attributes such as trust [39], a facilitator of collective action [40].

\subsection{Organizational Performance}

IC (including creativity and innovation) and knowledge management (sharing) are interlinked phenomena, which plays a very vital role in enhancing the productivity and output of an organization. They can be considered as components of a smooth process of evolution, which continues throughout in almost all of the organizations. Fiscal evaluation is one of the conventional method used to gauge the performance of an organization. Mostly the knowledge management performance is gauged through universal yield methods such as market allocation, profitability, development / expansion rate, innovation and the dimension of business in contrast with key rivals [41]. Intra-organizational KS is positively and significantly associated with financial performance [1]. A successful and renowned organization would yield better financial returns and reputation, which determines the competitive advantage of the organization.

In exchange of explicit knowledge within an organization can bring knowledge resources together into a driving force of financial performance. The high level of expertise in knowledge sharing helps to take advantage of the existing formal knowledge and expertise in integrated problem solving, which can improve products and processes [42]. [5], for example, found that once successful explicit knowledge sharing takes place directly in outsourcing projects, firms' financial outcomes would be enhanced. [43] Suggest that information sharing within organizations and between organizations helps organization members to identify critical problems and that leads to a better product quality improvement and financial performance.

Additionally, explicit knowledge sharing practices facilitate financial performance $[44,45]$ and innovation [44]. However, tacit knowledge is an essential part of experiential knowledge acquired by individuals during the course of (holistic) working; tacit knowledge sharing contains person; situation or context-oriented interactions. This practice stimulates organization members, groups and units to exchange their own experience or knowledge and think together, to bring enormous benefits to an organization [46, 47]. These benefits include less cost, improved delivery, fewer quality problems, early insights into new technologies, and on-time product launches [48, 49]. Law and Ngai [50], for example, found that tacit knowledge sharing led to the improvement of business processes, product and service offerings of a firm, and better operational performance.

\section{Theoretical Background \& Research Model}

A theory of IC provides three dimensions - human capital, structural capital, and relational capital [36]. Understanding IC requires that we recognise that a new employee (human capital) will not contribute to organisational performance with the supportive structures of an organisation (structural capital) and substantial market relationships and interorganisational links [34]. Following this theoretical lens on IC, existing studies [2, 28, 45, 51] indicate association between IC and knowledge management. Organizations that focus on their knowledge management practices to develop IC tend to perform better, and out compete others [28]. What existing studies ignore is the specific role of different knowledge management strategies towards IC for organisational performance and success. Moreover, organizations may need to recognize specific interactive effects between knowledge management and IC [52]. While extant literature focus on the effect of IC on knowledge management in the organization c.f. [28, 30, 53], Figure 1 elaborates the effects of an organization's knowledge sharing practices on its IC.

Knowledge management in the organisation is centered on the theory of knowledge creation [18]. While the theory is enriching and offers deep theoretical and practical insight, studies have not tested how core aspects in knowledge creation come together to support IC development. This study tests multiple aspects of the knowledge environment leading to IC and performance. One is knowledge sharing processes, which consist of two dimensions namely knowledge donating and knowledge collecting $[54,55]$. Hansen, Nohria [56] mention that knowledge intensive organizations should pursue either codification or personalization as a dominant strategy. 
Hansen, Nohria [56]'s concept of codification and personalization is widely cited in the literature on knowledge formulation - the process which employees mutually transfer and creates knowledge.

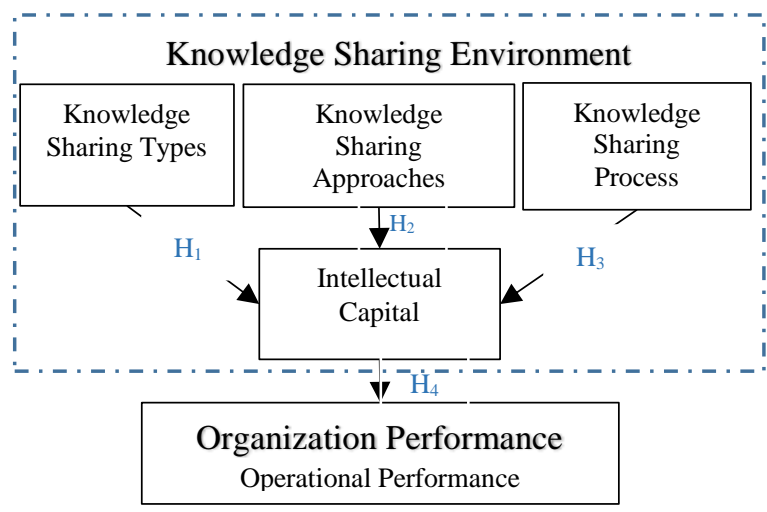

Figure 1. Research Model

Table 1. Description of Factors in the Research Model

\begin{tabular}{|c|l|c|}
\hline Factor & \multicolumn{1}{|c|}{ Description } & Source \\
\hline $\begin{array}{c}\text { Knowledge } \\
\text { Sharing Types }\end{array}$ & $\begin{array}{l}\text { Explicit knowledge is } \\
\text { knowledge that can } \\
\text { exist in symbolic or } \\
\text { written form. }\end{array}$ & {$[57]$} \\
& $\begin{array}{l}\text { Tacit knowledge is } \\
\text { often context } \\
\text { dependent and } \\
\text { personal in nature. }\end{array}$ & \\
\hline $\begin{array}{c}\text { Knowledge } \\
\text { Approaches }\end{array}$ & $\begin{array}{l}\text { Codification - } \\
\text { process through which } \\
\text { knowledge is captured } \\
\text { and stored in } \\
\text { electronic } \\
\text { repositories/databases } \\
\text { independent of the } \\
\text { individual that } \\
\text { generated knowledge } \\
\text { Personalization - } \\
\text { process through which } \\
\text { knowledge shared } \\
\text { through person-to- } \\
\text { person interaction or } \\
\text { through some } \\
\text { communication } \\
\text { channel. }\end{array}$ & [56], \\
\hline $\begin{array}{l}\text { Knowledge donating } \\
\text { is "the process of } \\
\text { individuals } \\
\text { communicating their }\end{array}$ & {$[54,55]$} \\
Process & \\
\hline & & \\
\hline
\end{tabular}

\begin{tabular}{|c|c|c|}
\hline & $\begin{array}{l}\text { personal IC to others" } \\
\text { while } \\
\text { Knowledge collecting } \\
\text { is the "process of } \\
\text { consulting colleagues } \\
\text { to encourage them to } \\
\text { share their IC." }\end{array}$ & \\
\hline $\begin{array}{l}\text { Intellectual } \\
\text { Capital }\end{array}$ & $\begin{array}{l}\text { Human capital "is } \\
\text { the sum of employees } \\
\text { "competence, } \\
\text { knowledge, skills, } \\
\text { innovativeness, } \\
\text { attitude, commitment, } \\
\text { wisdom, and } \\
\text { experience". } \\
\text { Structural capital is } \\
\text { described as "the } \\
\text { valuable strategic } \\
\text { assets of } \\
\text { organizational } \\
\text { capabilities, } \\
\text { organizational culture, } \\
\text { routines, procedures, } \\
\text { information systems, } \\
\text { hardware, software, } \\
\text { databases, company } \\
\text { images, patents, } \\
\text { copyrights, } \\
\text { trademarks, and so } \\
\text { on". } \\
\text { Relational capital } \\
\text { "the knowledge and } \\
\text { learning capabilities } \\
\text { that exist in } \\
\text { relationships between } \\
\text { an organization and its } \\
\text { external stakeholders". }\end{array}$ & $\begin{array}{l}{[45,59,} \\
60]\end{array}$ \\
\hline $\begin{array}{l}\text { Organisational } \\
\text { Performance }\end{array}$ & $\begin{array}{l}\text { Operational } \\
\text { performance refers to } \\
\text { the customer } \\
\text { satisfaction, cost } \\
\text { management and } \\
\text { productivity of the } \\
\text { company. }\end{array}$ & [45] \\
\hline
\end{tabular}

\section{Hypothesis Development}

\subsection{Knowledge Sharing Practices (KSP) and Intellectual Capital (IC) (Knowledge Environment)}

Organizations have to realize that 'the integration of IC and $\mathrm{KM}$ requires alignment of $\mathrm{KM}$ processes with IC assets to meet the organization's strategic 
needs' [61]. Although studies have not examined the role of knowledge donation and collection on the development of IC, knowledge processes, such as knowledge creation, tend to influence organizational performance through the mediating effect of IC [62]. One must recognize that the process of knowledge sharing is a facilitator for knowledge creation. Further still, knowledge-sharing processes tend to influence the organization's innovation capability and performance [51].

Defining the difference between tacit and explicit knowledge is very crucial in the development and utilization of IC [45]. To understand the organization's IC, one needs a clear understanding of the organization's knowledge types [63]. While some studies $[45,64]$ indicate that tacit knowledge is the most significant resource for IC development, others $[65,66]$ indicate that both types of knowledge are relatively crucial in the development of IC. In some cases, the organization has to convert tacit knowledge to explicit knowledge to increase its value towards organizational advantage [65, 66].

An appropriate decision on implementation of knowledge systems will help the organization achieve its enlisted and perceived aims / objectives [67]. Organisations select personalization and/or codification techniques as KM strategies in order to ensure that the information and knowledge can reach to the person it meant for [68]. Edvinsson and Sullivan [63], suggest 'there is a relationship between the degree of codification of knowledge and the amount of value it can be said to command'. Further still, the personalization approach influences ease of use, usefulness and user satisfaction of knowledge and KMS in the organization [69]. Ease of use and usefulness of knowledge are crucial for enabling valuable knowledge. Intellectual capital being the 'knowledge that can be converted into value' [63]. To improve organizational performance and value creation, there has to be a fit between the organization's IC and KM strategy [10, 70].

In this study, we identify three knowledge-sharing practices and examine their effect on IC of the organization. We state the following research questions and hypotheses.

Table 1. Research Question 1 and Hypothesis

\begin{tabular}{|l|l|}
\hline \multicolumn{1}{|c|}{ Research Questions } & \multicolumn{1}{c|}{ Hypothesis } \\
\hline Do knowledge-sharing & H1: Knowledge \\
practices of an & sharing types are \\
organization influence its & positively associated \\
IC? & with IC. \\
& H2: Knowledge \\
& sharing approaches \\
\hline
\end{tabular}

\begin{tabular}{|l|l|}
\hline & are positively \\
associated with IC. \\
H3: Knowledge \\
sharing process are \\
positively associated \\
with IC.
\end{tabular}

\subsection{Intellectual Capital (IC) and Organizational Operational Performance (OP)}

Organizations need to develop new strategies and policies to incorporate new trends to ensure operational and financial efficiency. Among such strategies is the need to focus on KM and the development of IC. Organizations with high levels of IC will perform better compared to those with low IC [28]. There are many measures of organizational performance associated with IC. IC fosters market performance of an organization [2, 71]. IC improves the organization's innovation performance, product development and brand performance $[2,60]$. Additionally, a survey of high technology firms in China, found that IC - human, structural and relational enhance operational and financial performance [45]. Similarly, IC is also strongly linked to operational efficiency of insurance firms in China [29]. In this study, we assess organizational performance from an operational perspective, and we hypothesize as indicated in Table 3 below.

Table 3. Research Question 2 and Hypothesis

\begin{tabular}{|l|l|}
\hline Research Questions & Hypothesis \\
\hline $\begin{array}{l}\text { Does intellectual capital } \\
\text { influence organizational } \\
\text { operational performance? }\end{array}$ & $\begin{array}{l}\text { H4: IC is positively } \\
\text { organizational with } \\
\text { performance. }\end{array}$ \\
\hline
\end{tabular}

\section{Methodology}

A cross-sectional survey was conducted among IT firms in Saudi Arabia. The survey lasted for three months starting from July 2017 - October 2017. Thirty-seven organizations from private, public, semipublic, and non-profit organisations participated in the survey. Participating organizations were selected randomly from the top 1000 firms listed by Saudi Arabia's Ministry of Labor. We contacted two hundred (200) potential participants and one hundred (160) completed the survey. After removing the missing responses, we obtained (150) usable responses. 
Previous validated survey instruments were used and modified to ensure the items reliability and validity. The knowledge sharing types items were modified from [45], knowledge sharing approaches was adapted from [58], knowledge sharing process was adopted from [51], IC was derived from [45]. The organizational performance was derived from [45].

Partial Least Squares structural equation modeling (PLS-SEM) a variance-based approach using SmartPLS 3.0 [72] is used to test the hypotheses. According to [73-75], PLS-SEM approach does not require a large sample size, does not require normality and subsequently works without distributional assumptions and with nominal, ordinal and intervalscaled variables. According to Henseler, Dijkstra [76] PLS-SEM performs better than covariance-based approach (CB-SEM) in finding the true model. Moreover, the benefits of PLS-SEM includes that it allows both reflective and formative factors to be analyzed together [77-79], which is the case in our study.

In this study, 'organization performance' is modeled as a reflective construct. Whereas all other factors, 'knowledge sharing types', 'knowledge sharing approaches', 'knowledge sharing process' and 'IC' are modeled as formative indicators because they are multidimensional construct, which covers various referent groups. Such as 'knowledge sharing types' consist of tacit and explicit knowledge, 'knowledge sharing approaches' consist of codification and personalization, 'knowledge sharing process' consist of collection and donation and 'IC' consist of human, structural and relational capital.

\section{Results}

A sample of 150 responses was used for data analysis. $70 \%$ of participants are male $30 \%$ are female. The distribution of the gender shows a fairly representation of the population of employees in the Saudi organizations. $45 \%$ of participants hold a bachelor's degree. $55 \%$ participants had more than 5 years of work experience.

\subsection{Reliability and Validity Tests}

The study follows a survey approach, which is commonly affected by common method bias (CMB). We tested for CMB through Harman's Single Factor Test, which provided $25 \%$ of variance in the first component. Additionally, we recognise the limitations of PLS-SEM, so we tested for multicollinearity, reliability and validity assessment of the formative indicators using outer weights and variance inflation factor (VIF) [80]. The validity of construct using outer weights was significant ( $\mathrm{p}$ value $<0.05)$. The reliability of formative indicators was measured using the variance inflation factor (VIF) value was less than 5 , which means there is no multicollinearity.

The reliability and validity assessment of the reflective construct were assessed for internal consistencies, convergent validity, and discriminant validity [81]. All values are in acceptable range. Internal consistency using Cronbach's $(\alpha)$ value is 0.83 . Convergent validity is assessed using average variance extracted $(\mathrm{AVE}=0.67)$ and the composite reliability $(\mathrm{CR}=0.89)$. The loadings of reflective indicator for 'organizational performance' exceeded a recommended value of 0.70 , which show the items reliability.

\subsection{Structural Model Testing}

The structural model analysis is performed to test the proposed hypotheses. The significance of the path coefficient was determined using with the bootstrapping technique. A 5\% significance level was employed for two-tailed test. Table 4 shows the structural model results. Figure 2 shows the path testing.

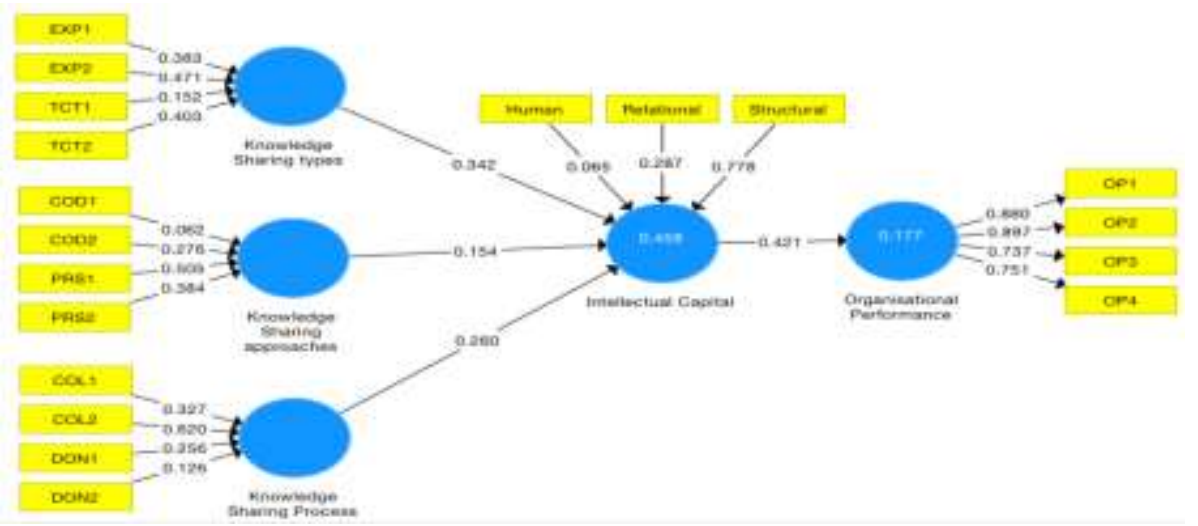

Figure 2. Path testing 
Table 4. Path testing

\begin{tabular}{|c|l|c|c|c|c|c|}
\hline & & $\begin{array}{c}\text { Sample } \\
\text { Mean }\end{array}$ & STDEV & T Statistics & $\begin{array}{c}\text { P } \\
\text { Values }\end{array}$ & Supported? \\
\hline H1 & Knowledge Sharing Types -> Intellectual Capital & 0.34 & 0.11 & 2.88 & 0.003 & Yes \\
\hline H2 & Knowledge Sharing Approaches -> Intellectual Capital & 0.16 & 0.12 & 1.23 & 0.21 & No \\
\hline H3 & Knowledge Sharing Process -> Intellectual Capital & 0.29 & 0.11 & $1 . .99$ & 0.002 & Yes \\
\hline H4 & Intellectual Capital -> Organizational Performance & 0.44 & 0.08 & 5.21 & 0.000 & Yes \\
\hline
\end{tabular}

The results show that 'knowledge sharing types', and 'knowledge sharing process' have a significant positive effect on 'IC'. Therefore, $\mathrm{H} 1$ and $\mathrm{H} 3$ are supported. The relationship between the 'IC' and 'organizational performance' is also significant. Therefore, $\mathrm{H} 4$ is also supported. However, $\mathrm{H} 2$ is not supported by the data, which because the relationship between 'knowledge sharing approaches' and the 'IC' is not significant. Moreover, $\mathrm{R}$ square $\left(\mathrm{R}^{2}\right)$ variance for 'IC' shows $45 \%$ variance towards 'organizational performance; in Saudi context. In addition, $\mathrm{R}^{2}$ of the 'organizational performance' is 0.17 .

\subsection{Importance-Performance Map Analysis}

In order to generate additional findings and conclusions for managerial actions, importanceperformance map analysis (IPMA) was also conducted ([82, 83]. Performing an IPMA involves determining a target factor, such as organizational performance in our research model. The performance is measured on the scale of 0 to 100 for each factor. The higher the value indicates the higher the performance of the factor. All total effects (importance) larger than 0.10 are significant at the $\mathrm{p} \leq 0.10$ level.

Table 5 and Figure 3 shows the IPMA results of all the indirect and direct predecessors of the target construct 'organizational performance'. The highest performance indirect construct is 'knowledge sharing approaches' followed by 'knowledge sharing process." This means the increase in 'knowledge sharing approaches' performance would increase the performance of the target construct "'organizational performance' by the size of the total effect value of 0.06 .

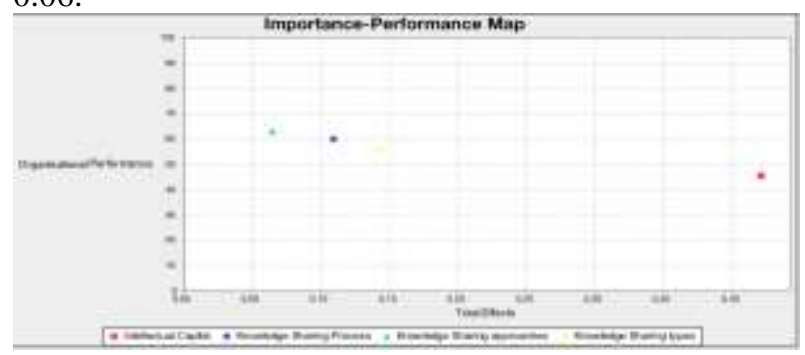

Figure 3. IPMA
Table 5. IPMA of the Target Construct (Organizational performance)

\begin{tabular}{|l|c|c|}
\hline & $\begin{array}{c}\text { Importance } \\
\text { (Total effects) }\end{array}$ & $\begin{array}{c}\text { Perfor } \\
\text { mance }\end{array}$ \\
\hline $\begin{array}{l}\text { Knowledge Sharing } \\
\text { Types }\end{array}$ & 0.14 & 56.14 \\
\hline $\begin{array}{l}\text { Knowledge Sharing } \\
\text { Approaches }\end{array}$ & 0.06 & 63.17 \\
\hline $\begin{array}{l}\text { Knowledge Sharing } \\
\text { Process }\end{array}$ & 0.10 & 60.07 \\
\hline Intellectual Capital & 0.42 & 45.59 \\
\hline
\end{tabular}

\section{Discussion}

\subsection{Theoretical Implications}

The study sought to establish whether knowledgesharing practices of an organization influence its IC and operational performance. This study argues that knowledge sharing types, both tacit and explicit, and knowledge sharing processes both knowledge collection and knowledge donation influence IC. Consequently, as earlier indicated by [45], IC influences the operational performance of an organization. However, IC development may not result from the knowledge sharing approaches/strategies of codification and personalization. It is evident, from findings, that focusing on collection and donation of both tacit and explicit knowledge will support IC.

\subsection{Practical Implications}

Our findings offer important implications for organisation managers. First, our results suggest that the organization's knowledge environment constitutes a combination of knowledge sharing practices and IC, where sharing tacit or explicit knowledge and the knowledge sharing processes used will strongly shape the IC development. Secondly, developing for codification or socialisation may not improve IC but encouraging donation and collection of tacit or explicit knowledge will develop IC. Thirdly, managers ought to remember that the knowledge-sharing environment 
affects the organization's operational performance due to its impact on IC development. IC development for organisational performance requires the organisation to focus on the types of knowledge shared throughout the organization, while balancing between knowledge collection and knowledge donation among employees.

\section{Conclusion}

The knowledge-sharing environment of an organization constitutes two important factors knowledge sharing practices and IC. The knowledge sharing practices constitute knowledge sharing types, knowledge sharing approaches and knowledge sharing processes. These three aspects represent the knowledge flows of the organization while IC represents the knowledge stocks of the organization. The learning point for practioners is that the knowledge sharing types, i.e. focusing on explicit knowledge sharing or tacit knowledge sharing affects the organization's stocks of knowledge. Additionally, fostering knowledge collection and knowledge donation also affects the organization's knowledge stock. It is more important for the organization to focus on the types of knowledge shared across the organization and the processes of knowledge collection and donation among individuals. Managers ought to realize that focusing on codification or personalization may not support IC development.

\section{References}

[1] M. Kaplan, et al., "The Relationship between Organisational Learning and Financial Performance: A Study of Small-Sized Business in Turkey", Journal of WEI Business and Economics, 2014, pp. 17-24.

[2] S. Cabrilo and S. Dahms, "How strategic knowledge management drives intellectual capital to superior innovation and market performance", Journal of Knowledge Management, 2018, pp. 621-648.

[3] J.N. Lee, The impact of knowledge sharing, organizational capability and partnership, quality on IS outsourcing success. Information \& Management, 2001, pp. 323-335.

[4] L. Argote, "Organizational learning: creating, retaining, and transferring knowledge", Kluwer Academic, 1999.

[5] Lee, J.-N., "The impact of knowledge sharing, organizational capability and partnership quality on IS outsourcing success", Information \& Management, 2001, pp. 323-335.

[6] J. Chatzkel, Intellectual Capital, ExpressExec Innovation, John Wiley and Sons, Inc., Oxford, United Kingdom, 2002.

[7] K. Henttonen, A. Kianto, and P. Ritala, "Knowledge sharing and individual work performance: an empirical study of a public sector organisation", Journal of Knowledge Management, 2016, pp. 749-768.
[8] D. Paulin and K. Suneson, Knowledge transfer, knowledge sharing and knowledge barriers-three blurry terms in KM. The Electronic Journal of Knowledge Management, 2012, pp. 81-91.

[9] F. Sardo and Z. Serrasqueiro, "A European empirical study of the relationship between firms' intellectual capital, financial performance and market value", Journal of Intellectual Capital, 2017, pp. 771-788.

[10] A. Kianto, et al., "The interaction of intellectual capital assets and knowledge management practices in organizational value creation", Journal of Intellectual capital, 2014, pp. 362-375.

[11] B. Van Den Hooff and J.A. De Ridder, "Knowledge sharing in context: the influence of organizational commitment, communication climate and CMC use on knowledge sharing", Journal of knowledge management, 2004, pp. 117-130.

[12] A. Dysvik, R. Buch, and B. Kuvaas, "Knowledge donating and knowledge collecting: The moderating roles of social and economic LMX", Leadership \& Organization Development Journal, 2015, pp. 35-53.

[13] Ambrosini, V. and C. Bowman, Tacit knowledge: Some suggestions for operationalization. Journal of Management studies, 2001, pp. 811-829.

[14] H. Tsoukas, "Do we really understand tacit knowledge?" Managing Knowledge: An Essential Reader, 2005, p. 107.

[15] L.A. Joia and B. Lemos, "Relevant factors for tacit knowledge transfer within organisations", Journal of knowledge management, 2010, pp. 410-427.

[16] C.-H. Wu, S.-C. Kao, and L.-H. Shih, Assessing the suitability of process and information technology in supporting tacit knowledge transfer. Behaviour \& Information Technology, 2010, pp. 513-525.

[17] S.R. Murray and J. Peyrefitte, "Knowledge type and communication media choice in the knowledge transfer process", Journal of Managerial Issues, 2007, pp. 111133.

[18] I. Nonaka and R. Toyama, "The knowledge-creating theory revisited: knowledge creation as a synthesizing process", Knowledge management research \& practice, 2003, pp. 2-10.

[19] E.A. Smith, "The role of tacit and explicit knowledge in the workplace", Journal of knowledge Management, 2001, pp. 311-321.

[20] C. McMahon, A. Lowe, and S. Culley, "Knowledge management in engineering design: personalization and codification", Journal of Engineering Design, 2004, pp. 307-325.

[21] R. Cowan and D. Foray, The economics of codification and the diffusion of knowledge. Industrial and corporate change, 1997. 6(3): p. 595-622.

[22] K. Dalkir, Knowledge Management in Theory and Practice, MIT Press.Cambridge, Mass., UNITED STATES, 2011.

[23] L. Argote, Organizational learning: Creating, retaining and transferring knowledge, Springer Science \& Business Media, New York, 2013.

[24] A. Prencipe and F. Tell, "Inter-project learning: processes and outcomes of knowledge codification in 
project-based firms", Research policy, 2001, pp. 13731394.

[25] A. Brooking, Intellectual capital: Core Asset for the Third Millenium Enterprise, International Thomson Business Press, New York, 1996.

[26] T. Andreeva and T. Garanina, "Do all elements of intellectual capital matter for organizational performance? Evidence from Russian context", Journal of Intellectual Capital, 2016, pp. 397-412.

[27] K. Asiaei, R. Jusoh, and N. Bontis, "Intellectual capital and performance measurement systems in Iran", Journal of Intellectual Capital, 2018, (just-accepted).

[28] H. Hussinki, et al., "Intellectual capital, knowledge management practices and firm performance", Journal of Intellectual Capital, 2017, pp. 904-922.

[29] W.-M. Lu, W.-K. Wang, and Q.L. Kweh, "Intellectual capital and performance in the Chinese life insurance industry" Omega, 2014, pp. 65-74.

[30] G. Radaelli, et al., "Intellectual capital and knowledge sharing: the mediating role of organisational knowledgesharing climate", Knowledge Management Research \& Practice, 2011, pp. 342-352.

[31] B.M. Ramadan, et al., "Intellectual capital, knowledge management and social capital within the ICT sector in Jordan", Journal of Intellectual Capital, 2017, pp. 437462.

[32] A.-A.A. Sharabati, S. Naji Jawad, and N. Bontis, "Intellectual capital and business performance in the pharmaceutical sector of Jordan", Management decision, 2010, pp. 105-131.

[33] C. Curado and N. Bontis, "Managing intellectual capital: the MIC matrix", International journal of knowledge and learning, 2007, pp. 316-328.

[34] N. Bontis, "Intellectual capital: an exploratory study that develops measures and models. Management decision, 1998, pp. 63-76.

[35] L. Edvinsson and M.S. Malone, Intellectual capital: Realizing your companyl's true value by finding its hidden brainpower. 1997.

[36] D.H. Luthy, "Intellectual capital and its measurement", Proceedings of the Asian Pacific Interdisciplinary Research in Accounting Conference (APIRA), Osaka, Japan. 1998.

[37] K.-H. Shih, C.-J. Chang, and B. Lin, "Assessing knowledge creation and intellectual capital in banking industry", Journal of intellectual capital, 2010, pp.74-89.

[38] E. Kong and M. Farrell, "Knowledge and learning capabilities in non-profit organizations: a relational capital perspective", The International Journal of Learning, 2010, pp. 97-116.

[39] S. Carey, B. Lawson, and D.R. Krause, "Social capital configuration, legal bonds and performance in buyersupplier relationships", Journal of Operations Management, 2011, pp. 277-288.

[40] J.S. Coleman, "Commentary: Social institutions and social theory", American Sociological Review, 1990, pp. 333-339.

[41] S.A. Drew, "From knowledge to action: the impact of benchmarking on organizational performance. Long range planning, 1997, pp. 427-441.
[42] B. Lawson, et al., "Knowledge sharing in interorganizational product development teams: The effect of formal and informal socialization mechanisms. Journal of Product Innovation Management, 2009, pp. 156-172.

[43] A.S. Carr and H. Kaynak, "Communication methods, information sharing, supplier development and performance: an empirical study of their relationships. International Journal of Operations \& Production Management, 2007, pp. 346-370.

[44] Z. Wang and N. Wang, "Knowledge sharing, innovation and firm performance", Expert systems with applications, 2012, pp. 8899-8908.

[45] Z. Wang, N. Wang, and H. Liang, "Knowledge sharing, intellectual capital and firm performance", Management decision, 2014, pp. 230-258.

[46] C.T. Matthew, and R.J. Sternberg, "Developing experience-based (tacit) knowledge through reflection", Learning and Individual Differences, 2009, p. 530-540.

[47] M. van Woerkom and K. Sanders, "The romance of learning from disagreement. The effect of cohesiveness and disagreement on knowledge sharing behavior and individual performance within teams", Journal of business and psychology, 2010, pp. 139-149.

[48] I.-C. Hsu, "Knowledge sharing practices as a facilitating factor for improving organizational performance through human capital: A preliminary test", Expert Systems with applications, 2008, pp. 1316-1326.

[49] P.J. Sher and V.C. Lee, "Information technology as a facilitator for enhancing dynamic capabilities through knowledge management", Information \& management, 2004, pp. 933-945.

[50] C.C. Law and E.W. Ngai, "An empirical study of the effects of knowledge sharing and learning behaviors on firm performance", Expert systems with applications, 2008, pp. 2342-2349.

[51] S.-H. Liao, W.-C. Fei, and C.-C. Chen, "Knowledge sharing, absorptive capacity, and innovation capability: an empirical study of Taiwan's knowledge-intensive industries", Journal of information science, 2007, pp. 340-359.

[52] Y.-C. Huang, and Y.-C. Jim Wu, "Intellectual capital and knowledge productivity: the Taiwan biotech industry", Management decision, 2010, pp. 580-599.

[53] M.E. Zaei and P. Kapil, "The role of intellectual capital in promoting knowledge management initiatives", Knowledge Management \& E-Learning, 2016, pp. 317.

[54] B. Van den Hooff and F. de Leeuw van Weenen, Committed to share: commitment and CMC use as antecedents of knowledge sharing. Knowledge and process management, 2004, pp. 13-24.

[55] C.-P. Lin, To share or not to share: Modeling tacit knowledge sharing, its mediators and antecedents. Journal of business ethics, 2007, pp. 411-428.

[56] M.T. Hansen, N. Nohria, and T. Tierney, "What's your strategy for managing knowledge", Harvard business review, 1999, pp. 106-116.

[57] I. Nonaka, "A dynamic theory of organizational knowledge creation", Organization science, 1994, pp. 14-37. 
[58] B. Choi and H. Lee, "An empirical investigation of KM styles and their effect on corporate performance. Information \& Management, 2003, pp. 403-417.

[59] I.M. Herremans, et al., "Intellectual capital and uncertainty of knowledge: control by design of the management system", Journal of business ethics, 2011, pp. 627-640.

[60] Y.-H. Hsu and W. Fang, "Intellectual capital and new product development performance: The mediating role of organizational learning capability", Technological Forecasting and Social Change, 2009, pp. 664-677.

[61] A.Z. Zhou and D. Fink, "The intellectual capital web: a systematic linking of intellectual capital and knowledge management. Journal of intellectual capital, 2003, pp. 34-48.

[62] G. Mehralian, J.A. Nazari, and P. Ghasemzadeh, "The effects of knowledge creation process on organizational performance using the BSC approach: the mediating role of intellectual capital" Journal of Knowledge Management, 2018.

[63] L. Edvinsson and P. Sullivan, "Developing a model for managing intellectual capital", European management journal, 1996, pp. 356-364.

[64] H. Saint-Onge, "Tacit knowledge the key to the strategic alignment of intellectual capital", Planning Review, 1996, pp. 10-16.

[65] C.O. Egbu, "Managing knowledge and intellectual capital for improved organizational innovations in the construction industry: an examination of critical success factors", Engineering, Construction and Architectural Management, 2004, pp. 301-315.

[66] K.M. Wiig, "Integrating intellectual capital and knowledge management”, Long Range Planning, 1997, pp. 399-405.

[67] A. Carmeli and B. Azeroual, "How relational capital and knowledge combination capability enhance the performance of work units in a high technology industry", Strategic entrepreneurship journal, 2009, pp. 85-103.

[68] P. Moran, "Structural vs. relational embeddedness: social capital and managerial performance". Strategic Management Journal, 2005, pp. 1129 - 1151.

[69] J.-Y. Lai, C.-T. Wang, and C.-Y. Chou, "How knowledge map fit and personalization affect success of KMS in high-tech firms", Technovation, 2009, pp. $313-$ 324.

[70] Z. Wang, et al., "The impact of intellectual capitalknowledge management strategy fit on firm performance", Management Decision, 2016, pp. 18611885.

[71] V. Dzenopoljac, et al., "Impact of intellectual capital on corporate performance: evidence from the Arab region", Journal of Intellectual Capital, 2017, pp. 884-903.

[72] C.M. Ringle, S. Wende, and J.-M. Becker. Smartpls 3. Hamburg: SmartPLS. 2014 [cited 2014; Available from: http://www.smartpls.com.

[73] M. Haenlein and A.M. Kaplan, A Beginner's Guide to Partial Least Squares Analysis. Understanding Statistics, 2004. 3(4): p. 283-297.

[74] F. Hair, et al., Partial least squares structural equation modeling (PLS-SEM) An emerging tool in business research. European Business Review, 2014, pp. 106121.

[75] J.F. Hair, C.M. Ringle, and M. Sarstedt, PLS-SEM: Indeed a Silver Bullet. Journal of Marketing Theory and Practice,, 2011, pp. 139-151.

[76] J. Henseler, et al., "Common Beliefs and Reality About PLS”, Organizational Research Methods, 2014, pp. 182209.

[77] W.W. Chin, B.L. Marcolin, and P.R. Newsted, "A partial least squares latent variable modeling approach for measuring interaction effects: results from a monte carlo simulation study and an electronic-mail emotion/adoption study", Information Systems Research, 2003, pp. 189-217.

[78] F. Hair, et al., "Partial least squares structural equation modeling (PLS-SEM): An emerging tool in business research", European Business Review, 2014, pp. 106121.

[79] M. Sarstedt, C.M. Ringle, and J.F. Hair, "Partial Least Squares Structural Equation Modeling", Handbook of Market Research, C. Homburg, M. Klarmann, and A. Vomberg, Editors, Springer International Publishing: Cham, 2017, pp. 1-40.

[80] J.F. Hair Jr, et al., A primer on partial least squares structural equation modeling (PLS-SEM), Sage Publications, 2016.

[81] C. Fornell, and D.F. Larcker, "Evaluating structural equation models with unobservable variables and measurement error", Journal of marketing research, 1981, pp. 39-50.

[82] M.R. Christian and M. Sarstedt, "Gain more insight from your PLS-SEM results: The importance-performance map analysis", Industrial Management \& Data Systems, 2016, pp. 1865-1886.

[83] C. Hock, C. Ringle, and M. Sarstedt, "Management of Multi-Purpose Stadiums: Importance and Performance Measurement of Service Interfaces", International Journal of Services Technology and Management, 2010, pp. 188-207. 